\title{
Perceived Employability: Peranan Career Calling dan Strategi Karir sebagai Mediator
}

\author{
Diyah Arini Lestari \\ Erika Setyanti Kusumaputri \\ Fakultas Ilmu Sosial dan Humaniora, UIN Sunan Kalijaga Yogyakarta \\ Email: ariniediy@ymail.com
}

\begin{abstract}
This study aims to determine the relationship between career calling and perceived employability through career strategies as mediator on professional workers in Yogyakarta. Participants in this study are professional workers totaling 48 workers $(\mathrm{N}=48)$. Perceived employability scale, career calling scale and career strategy scale were used for data collection. Path analysis with bootstrapping techniques were used to analyze the data. The results of path analysis showed there is a direct influence of career calling on perceived employability without going through career strategy.
\end{abstract}

Keywords: career calling, perceived employability, career strategies

\section{INTISARI}

Penelitian ini bertujuan untuk menguji hubungan antara career calling dan employability dengan strategi karir sebagai mediator pada pegawai profesional. Responden dalam penelitian ini terdiri dari 48 pegawai. Skala yang digunakan dalam penelitian ini adalah skala perceived employability, skala career calling dan skala strategi karir. Analisis jalur (path analysis) dengan bootstrapping digunakan sebagai metode analisis data. Hasil analisis jalur menunjukkan terdapat pengaruh langsung dari career calling terhadap employability tanpa melalui strategi karir.

Kata kunci: career calling, perceived employability, strategi karir

$\mathrm{K}$

emampuan individu untuk bekerja sesuai dengan bidang keahliannya merupakan salah satu hal yang sangat penting bagi organisasi maupun bagi calon tenaga kerja (De Cuyper, Van Der Heijden \& De Witte, 2011). Hasil survei yang dilakukan oleh Badan Pusat Statistik (BPS) Nasional pada bulan Mei 2014 menunjukkan angka pengangguran di Indonesia sebesar 7,2 juta jiwa dan $54 \%$ diantaranya disebabkan karena adanya ketidaksesuaian pekerjaan dengan keahlian yang dimilikinya (pendidikan) (JobStreet.co.id, 2014). Pemberitaan tersebut memberikan pemahaman bahwa tidak semua individu mampu mengenali keahlian dalam bekerjanya dengan baik. Kemampuan individu dalam memahami keahlian bekerja yang sesuai dengan bidangnya merupakan wujud perceived employability.

Perceived employability merupakan penilaian individu untuk mengenali keahlian yang dimilikinya, pencapaian terhadap tujuan karir dan keuntungan lain yang mungkin akan diperoleh dari pekerjaannya (Fugate, Kinicki \& Ashforth, 2004). Fugate dan Kinicki (2008) menyebutkan bahwa perceived employability pada karyawan berhubungan dengan perilaku adaptif yang akan dikembangkannya dan kemampuan melakukan kontrol diri dalam bekerja sehingga dapat menunjukkan kinerja terbaik mereka pada organisasi. Tingkat perceived employability pada karyawan tidak dapat dilepaskan dari indikatorindikator yang mempengaruhinya. 
Secara rinci, Fugate, Kinicki dan Ashfort (2004) menyebutkan bahwa konsep perceived employability akan memungkinkan karyawan sebagai pribadi pusat adaptasi aktif yang terlihat dari ketiga aspek berikut ini, yakni (a) identitas karir, merupakan kemampuan untuk mendefinisikan diri dalam konteks pekerjaan yang meliputi identitas peran, identitas pekerjaan dan identitas organisasi; (b) adaptasi pribadi, merupakan kemampuan dalam menghadapi berbagai perubahan situasi dalam karir melalui peningkatan pengetahuan, keterampilan, kemampuan dan karakteristik lain yang berhubungan seperti tindakan pro-aktif, optimis, keinginan untuk selalu belajar, fleksibilitas pribadi dan efikasi diri; serta (c) kapital sosial, merupakan jaringan sosial yang akan mengarahkan pada kemampuan interpersonal dan kesediaan informasi melalui jaringan kerja yang akan membantu individu untuk memahami peluang karir dan perkembangan organisasi.

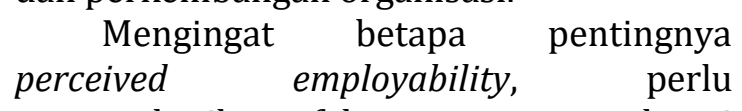
memperhatikan faktor yang mendasari tinggi rendahnya pemahaman individu terhadap perceived employability terutama pada pekerja profesi. Pekerja profesi dituntut untuk memiliki kompetensi kerja sesuai syarat dan harus memenuhi standar yang telah ditetapkan dimana di dalamnya terkandung nilai-nilai dan kode etik profesi (BNSP, 2011). Faktor yang mempengaruhi tinggi rendahnya pemahaman perceived employability tersebut terdiri dari faktor situasional dan faktor sumber daya individu. Berntson (2008) menyebutkan bahwa faktor situasional merupakan faktor pokok yang mempengaruhi perceived employability individu dan dapat dilihat dari; (a) keadaan struktural pasar tenaga kerja; (b) peluang karir, (kenaikan gaji, kondisi kerja yang lebih baik, stabilitas kerja, perubahan karir yang lebih baik dan keadilan dalam karir); dan (c) organisasi (regulasi kebijakan).

Sedangkan faktor sumber daya individu memainkan peran mendasar terhadap perceived employability yang dikembangkan oleh individu dan terdiri dari; (a) pengetahuan, keterampilan, keahlian dan potensi yang dipelajari dari pendidikan formal atau kejuruan dan pengalaman (Rothwell, Herbert \& Rothwell, 2008); (b) evaluasi subjektif untuk mengubah suatu keadaan sebagai bentuk motivasi guna mencapai tujuan karir (Rajan et. al dalam Rothwell dan Arnold, 2007; De Cuyper, Venhercke, Peeters \& De Witte, 2014); (c) kemampuan berhubungan dengan jaringan yang menyediakan informasi dan dukungan( Fugate, Kinicki \& Ashforth, 2004; Berntson, 2008); (d) kemampuan fleksibilitas pribadi untuk dapat beradaptasi secara lebih mudah (Van der Heijde \& Van der Heijden, 2006; Van der Heijden dalam De Cuyper, Vanhercke, Peeters \& De Witte, 2014); (e) keadaan demografis (usia dan jenis kelamin) dan kepribadian (watak) (Berntson, 2008); (f) kemampuan menggunakan strategi karir yang adaptif berguna untuk perkembangan karir, kemampuan eksplorasi karir, pencapaian tujuan,

Indikator perceived employability dapat muncul dari dalam (internal) maupun dari luar (eksternal) (Rothwell dan Arnold, 2007). Indikator internal muncul karena adanya penilaian individu terhadap kegunaan dirinya sebagai seorang "pekerja" dan menunjukkan adanya kecocokan terhadap lingkungan kerjanya melalui penggunaan strategi karir yang adaptif. Sedangkan indikator eksternal berasal dari kecocokan individu dengan pekerjaan lain yang lebih baik dengan berdasarkan pada kesamaan pengalaman kerja maupun kesamaan organisasi. Selain itu, terdapat faktor lain yang mempengaruhi tingkat perceived employability individu yakni sumber career calling (Praskova, Creed \&Hood, 2015). Career calling yang dirasakan oleh individu didorong oleh adanya keinginan untuk menjalani pekerjaan dengan penuh kecintaan (religiusitas) maupun adanya keinginan untuk mengejar keuntungan pribadi (sekuler) (Hall \& Chandler, 2005). Studi ini membatasi diri pada salah satu faktor perceived employability sebagai variabel bebas, yakni career calling sebagai religiusitas yang terdiri atas orientasi tindakan, rasa akan kejelasan tujuan dan misi pribadi, serta menunjukkan adanya tujuan pro-sosial.

Individu dengan career calling akan 
membuatnya merasa bahwa pekerjaan yang dilakukan merupakan sesuatu yang dapat memberikan makna dalam hidupnya dan bukan hanya sebatas untuk mencari keuntungan material secara pribadi (Wrzesniewski, et al dalam Dik \& Duffy, 2009). Selain itu, karyawan dengan career calling akan lebih mencintai pekerjaannya dan melalui pekerjaan tersebut akan berkontribusi untuk membuat dunia menjadi lebih baik. Lebih lanjut, Dik dan Duffy (2009) menerangkan bahwa career calling merupakan bentuk religiusitas dalam bekerja yang mengarah kepada adanya panggilan untuk setiap pekerjaan yang menciptakan rasa akan tujuan dan memberikan kebermaknaan secara pribadi atas pemenuhan nilai-nilai lain sebagai sumber motivasi utama dalam bekerja. Nilai-nilai tersebut dapat dilihat dari adanya dorongan hati yang datangnya dari Tuhan untuk membantu individu lain melalui pekerjaannya karena pada dasarnya kodrat manusia adalah makhluk sosial.

Elangovan, Pinder dan McClean (2010) melengkapi penelitian yang dilakukan oleh Dik dan Duffy (2009) dengan menegaskan bahwa career calling adalah serangkaian tindakan pencarian untuk mewujudkan tujuan pro-sosial sebagai perasaan individu terhadap apa yang mereka ingin lakukan kepada individu lain melalui pekerjaannya, sesuatu yang seharusnya boleh mereka kerjakan dan sesuatu yang tidak seharusnya mereka kerjakan. Hal ini memberikan pemahaman bahwa career calling merupakan sebuah kebenaran dalam karir dengan memperhatikan aspek positif yang berhubungan dengan pekerjaan tersebut. Selain itu, career calling sebagai religiusitas dalam bekerja merupakan sebuah dorongan yang datangnya dari Tuhan untuk melayani individu lain (Bunderson \& Thompson dalam Praskova, Creed \& Hood, 2015). Tasmara (2002) menjelaskan secara lebih spesifik dalam sudut pandangan islam terkait career calling bahwa pada dasarnya setiap muslim memiliki jiwa untuk melayani (stewardship) dengan berdasarkan pada keterpanggilan yang suci guna mengislamkan kehidupannya dan menghidupkan nilai-nilai keislaman terutama dalam bekerja.
Ketika bekerja, seorang muslim hendaknya selalu berbuat sesuatu yang penuh manfaat (shalih) dan melibatkan adanya kesadaran individu untuk mengetahui peran diri (makrifat: "aku tahu"), mengetahui langkah tujuan (hakikat: "aku berharap") serta dapat menentukan tindakan yang benar dan tepat (syariat: "aku berbuat"). Menurut Elangovan, Pinder dan McLean (2010) menerangkan bahwa career calling memiliki tiga fitur pendorong dasar, yakni; (a) orientasi tindakan, merupakan tindakan untuk mewujudkan career calling melalui kesadaran diri dan pedoman yang berasal dari dalam diri secara implisit; (b) rasa akan kejelasan tujuan dan misi pribadi; dan (c) tujuan pro-sosial, merupakan keinginan untuk membuat dunia menjadi lebih baik melalui pemilihan karirnya melalui program kerja yang memberikan manfaat bagi kehidupan orang lain atau program kerja kemanusiaan. Kesesuaian pekerja dengan dorongan career calling membuatnya merasa bahwa pekerjaan yang dilakukan merupakan sesuatu yang memberikan makna dalam hidup dan menjalaninya dengan penuh kecintaan, lebih bertanggung jawab, lebih berkomitmen, berguna bagi orang lain, meningkatkan kualitas kerja serta menunjukkan loyalitas (Wrzesniewski, et al dalam Dik \& Duffy, 2009; Elangovan, Pinder \& McClean, 2010; Creed, Rogers, Praskova \& Searle, 2014). Selain itu, career calling yang dirasakan akan mendorong pekerja untuk dapat membantu individu lain melalui pekerjaannya, menunjukkan adanya kepedulian terhadap nilai kemanusiaan sehingga akan memperoleh kebahagiaan dan meningkatkan kebermaknaan diri serta menjadi investasi yang kelak akan dipetik.

Salah satu faktor internal diduga berfungsi sebagai variabel mediator, yaitu "strategi karir" yang berupa memperluas keterlibatan kerja. Pemilihan ini didasari oleh suatu dugaan bahwa kedua faktor tersebut mempengaruhi pemahaman individu terhadap perceived employability. Praskova, Creed dan Hood (2015) menyebutkan bahwa strategi karir merupakan sebuah bentuk mekanisme pengaturan perilaku yang dilakukan oleh individu dan dipandang sebagai sebuah cara untuk dapat mencapai profesionalitas 
dalam bekerja. Strategi karir menurut Greenhaus, Callanan dan Godshalk (2000) didefinisikan sebagai serangkaian tindakan yang mungkin digunakan oleh pekerja untuk mencapai tujuan karir. Untuk mengembangkan tujuan dan strategi dalam karir, perlu adanya manajemen karir diri (Lau \& Pang, 2000). Hal tersebut bagi pekerja untuk memahami tujuan jangka pendek maupun tujuan jangka panjang dengan mengadaptasi strategi yang berguna terhadap kemajuan karir dan menguatkan posisi pekerjaan.

Strategi karir memiliki tujuh tipe strategi yang dapat digunakan oleh pekerja untuk meningkatkan karirnya (Greenhaus, Callanan, \& Godshalk, 2000), yakni (a) kemampuan dalam pekerjaan saat ini, merupakan usaha yang dilakukan untuk mengetahui efektivitas kinerjanya melalui peningkatan kemampuan diri; (b) memperluas keterlibatan kerja, merupakan keputusan untuk menyediakan sejumlah waktu, energi dan emosi secara sungguhsungguh terhadap peran kerjanya (lembur, memikirkan kemajuan karir); (c) mengembangkan keterampilan, merupakan usaha karyawan untuk menambah keterampilan yang berhubungan melalui pendidikan berkelanjutan, pelatihan, pengalaman kerja, bergabung dengan asosiasi pekerja, mencari pekerjaan sampingan yang relevan, dll; (d) mengembangkan peluang, merupakan tindakan untuk meningkatkan pilihan karir melalui nominasi diri, penunjukan prestasi dan aspirasi, tugas lain yang diinginkan serta memperluas jaringan kerja; (e) membangun hubungan mentor dan aliansi pendukung lainnya; (f) membangun kesan dan reputasi; (g) politik organisasi, merupakan usaha yang dilakukan dengan menggunakan rayuan, kecocokan dengan atasannya dan membentuk koalisi dengan orang lain di dalam organisasi sehingga dapat mencapai hasil yang diinginkan.

Pada penelitian ini, peneliti memilih tipe strategi karir berupa "memperluas keterlibatan kerja". Tipe tersebut dipilih mengingat bahwa pekerja profesi memiliki keinginan untuk dapat bekerja secara sungguh-sungguh dan menunjukkan adanya komitmen terhadap organisasi (Greenhaus, Callanan \& Godshalk, 2000). Lau dan Pang
(2000) berpendapat bahwa seorang pekerja dapat menerapkan strategi karir sebagai upaya untuk membuatnya lebih termotivasi dalam mencapai tujuan karir. Penerapan penggunaan strategi karir dalam bekerja dapat disesuaikan dengan tujuan dan posisi karirnya sehingga akan memberikan kemungkinan perbedaan penggunaan tipe strategi karir oleh tiap individu sesuai kebutuhan dan sosial budayanya (Greenhaus, Callahnan \& Godshalk, 2000). Berkaitan dengan uraian diatas, hipotesis yang diajukan dalam penelitian ini dapat dirumuskan sebagai berikut; (a) hipotesis mayor: "Terdapat hubungan positif antara career calling terhadap perceived employability yang dimediasi oleh strategi karir pada pekerja profesi di Kota Yogyakarta"; (b) hipotesis minor: "Terdapat hubungan positif antara career calling terhadap perceived employability pada pekerja profesi di Kota Yogyakarta".

\section{Subjek Penelitian}

\section{Metode Penelitian}

Teknik pengambilan sampel dalam penelitian ini menggunakan teknik proporsional quota sampling, yaitu pengambilan sampel sebanyak jumlah tertentu yang dianggap dapat merefleksikan ciri populasi berdasarkan pada Tabel Krejcie dan Morgan (taraf keyakinan penelitian 90\% dan alpha 0.1) dan melalui tahapantahapan. Tahapan pengambilan sampel adalah sebagai berikut: Pertama, memilih sampel pekerja profesi yang berada di Kota Yogyakarta menggunakan batasan pekerja profesi dengan berpedoman pada Klasifikasi Buku Jenis Pekerjaan Indonesia (BPS, 2002) dan Badan Nasional Sertifikasi Profesi (BNSP, 2011) yang terdiri dari profesi arsitek, dokter dan psikolog. Kedua, mengambil sampel sesuai kuota dari organisasi yang menaunginya. Pada profesi arsitek, sampel ditentukan oleh organisasi profesi yakni IAI (Ikatan Arsitek Indonesia) DIY. Pada profesi psikolog, sampel diperoleh sesuai rekomendasi dari HIMPSI (Himpunan Psikologi Indonesia) Yogyakarta sedangkan pada profesi dokter, sampel diambil dari beberapa rumah sakit umum di Kota Yogyakarta.

Ketiga, menentukan teknik pengumpulan data dengan masing-masing 
lembaga atau organisasi yang menaunginya. Pada profesi arsitek pengambilan data dilakukan melalui email dibawah kendali IAI dengan perolehan sampel akhir sebanyak 12 orang, pada profesi dokter pengambilan data dilakukan oleh staf masing-masing rumah sakit yang memiliki wewenang dengan perolehan sampel akhir sebanyak 19 orang. Sedangkan pada profesi psikolog, pengambilan data dilakukan secara mandiri dengan perolehan sampel akhir sebanyak 17 orang.

\section{Instrumen Penelitian}

Penelitian ini menggunakan skala psikologi yang terdiri dari skala perceived employability, skala career calling dan skala strategi karir. Masing-masing instrumen dikembangkan sendiri oleh peneliti dengan berdasarkan hasil professional judgement (pendapat profesional) dan diujicobakan guna mengetahui tingkat validitas dan reliabilitasnya. Perhitungan validitas instrumen menggunakan statistik koefisiensi korelasi aitem total $\left(r i_{x}\right)$ dengan batasan $\geq 0.30$. Angka ini telah memenuhi syarat validitas untuk menjaring data penelitian sehingga diketahui bahwa skala perceived employability yang terdiri dari 78 aitem menjadi 54 aitem valid, skala career calling yang terdiri dari 60 aitem menjadi 35 aitem valid dan skala strategi kari yang terdiri dari 12 aitem menjadi 7 aitem valid. Sedangkan reliabilitasnya, dihitung menggunakan teknik komputasi dengan rumus Alpha atau koefisien cronbach alpha $(\alpha)$ sehingga dapat diketahui bahwa skala perceived employability memiliki reliabilitas sebesar 0.898, skala career calling memiliki reliabilitas sebesar 0.880 dan skala strategi karir memiliki reliabilitas sebesar 0.717 . Hasil perhitungan tersebut menunjukkan tingkat reliabilitas yang cukup tinggi mendekati 1.00 (Azwar, 2011).

\section{Hasil dan Pembahasan}

Berdasarkan perhitungan analisis jalur (path analysis) (Tabel 1), diketahui bahwa terdapat hubungan yang signifikan antara career calling terhadap perceived employability pada pekerja profesi di Kota Yogyakarta $(\beta)=1.279$, Sig $=0.000$. Selain itu, diketahui bahwa tidak terdapat hubungan yang signifikan antara career calling dan perceived employability dengan dimediasi strategi karir $\left(\mathrm{t}_{\text {hitung }}=-0.035<\mathrm{t}\right.$ tabel). Oleh karena itu, dilakukan uji hipotesis bootstrapping untuk mengetahui peran mediator pada sampel yang relatif kecil (Ghozali, 2011). Hasil uji bootstrapping (Tabel 2) menunjukkan hal yang sama bahwa terdapat hubungan yang signifikan antara career calling terhadap perceived employability pada pekerja profesi di Kota Yogyakarta $(\beta)=1.2781$, sig $=0.000$ serta strategi karir tidak dapat menjadi mediasi antara hubungan tersebut $\left(\mathrm{t}_{\text {hitung }}=-0.0260\right.$ $\left.<\mathrm{t}_{\text {tabel }}\right)$.

Tabel 1 Koefisien Regresi Pengaruh Langsung Variabel Eksogen (Independen) terhadap Endogen (Dependen) Berdasarkan Uji Path Analysis

\begin{tabular}{|c|c|c|c|c|}
\hline Jalur & Variabel eksogen & Variabel endogen & Direct Effect & Sig. \\
\hline p1 & Calling & Perceived & 1.279 & .000 \\
\hline p2 & Calling & Strategi &. .002 & .955 \\
\hline p3 & Strategi & Perceived & .263 & .542 \\
\hline
\end{tabular}

Tabel 2 Pengaruh Langsung dan Pengaruh Total Berdasarkan Uji Bootstrapping

\begin{tabular}{|c|c|c|c|}
\hline Direct & Variabel & Koefisien & Sig. \\
\hline $\mathrm{b}(\mathrm{YX})$ & Calling-Perceived & 1.2781 & .0000 \\
\hline $\mathrm{b}(\mathrm{MX})$ & Calling-Strategi & -0.0020 & .9550 \\
\hline $\mathrm{b}(\mathrm{YM} . \mathrm{X})$ & $\begin{array}{c}\text { Strategi-Perceived, } \\
\text { mengontrol Calling }\end{array}$ & 0.2635 & .5423 \\
\hline $\mathrm{b}(\mathrm{YX} . \mathrm{M})$ & $\begin{array}{c}\text { Calling-Perceived, } \\
\text { mengontrol Strategi }\end{array}$ & 1.2786 & .0000 \\
\hline
\end{tabular}


Hipotesis pertama tidak terbukti setelah data diolah melalui perhitungan path analysis dengan uji bootstrapping dan uji lanjut sobel test. Hal ini ditunjukkan oleh hasil perhitungan melalui uji sobel test berdasarkan uji path analysis menunjukkan $\mathrm{t}_{\text {hitung }}=-0.035<\mathrm{t}$ tabel sedangkan berdasarkan uji bootstrapping menunjukkan $t_{\text {hitung }}=-0.0260<t_{\text {tabel }}$. Disimpulkan bahwa strategi karir tidak dapat memediasi hubungan antara career calling terhadap perceived employability pada pekerja profesi di Kota Yogyakarta.

Hipotesis kedua diterima, hal ini ditunjukkan oleh hasil perhitungan path analysis dengan uji bootstrapping. Rerata skor strategi karir menunjukkan hasil yang sedang $(72.92 \%)$ berbeda dengan rerata skor perceived employability yang menunjukkan hasil tinggi $(72.92 \%)$ dan rerata skor career calling yang juga menunjukkan hasil tinggi (79.17\%). Oleh karena itu, disimpulkan bahwa terdapat interaksi antara career calling terhadap perceived employability pada pekerja profesi.

Hubungan antara career calling terhadap perceived employability dapat terjadi tanpa melalui strategi karir sebagai mediator. Hal ini menunjukkan bahwa hasil penelitian ini sejalan dengan teori. Kesesuaian career calling yang dimiliki muncul dari dorongan diri yang kuat dan merupakan tujuan hidupnya serta dapat meningkatkan pemahaman terhadap perceived employability. Ketika seseorang mendedikasikan pekerjaannya untuk orang lain, menikmati pekerjaannya, merasa lebih bermakna, merasa bahagia dan bangga terhadap pekerjaannya serta pekerjaan yang dilakukan sebagai bentuk ibadah, hal ini menandakan bahwa orang tersebut dapat mengenali career calling sebagai religiusitas (Hall \& Chandler, 2005). Para pekerja profesi dapat menggunakan kemampuan yang dimilikinya untuk mencapai tujuan karir, menunjukkan sikap yang lebih baik, menggunakan serangkaian tindakan yang tepat sesuai hati nuraninya serta memaksimalkan dalam mencapai hasil yang baik dari pekerjaan yang dilakukannya bagi diri sendiri maupun orang lain.

Lebih lanjut, orientasi individu dalam bekerja dapat berpengaruh terhadap tanggung jawab dan loyalitas terhadap organisasi sebagaimana dijelaskan oleh Praskova, Creed dan Hood (2015) dapat mempengaruhi penggunaan strategi karir seorang pekerja. Career calling yang dirasakan akan mendorong individu untuk dapat mencapai persepsi positif terhadap kesuksesan karir melalui strategi dan berdampak positif terhadap perceived employability individu (Praskova, Hood \& Creed, 2014).

Dik dan Duffy (2009) menjelaskan bahwa individu dengan career calling sebagai religiusitas tidak membuatnya untuk mengejar bagaimana idealnya karir tetapi ia akan belajar bagaimana untuk membingkai ulang tanggung jawab mereka dengan cara mengenali kemampuan yang dimiliki dan mengenali sumber career calling. Hal ini menandakan bahwa career calling dapat mempengaruhi perceived employability tanpa melalui strategi karir. Artinya, strategi karir tidak dapat menjadi penguat hubungan antara career calling dan perceived employability.

Greenhaus, Callanan dan Godshalk (2000) menerangkan bahwa keputusan menggunakan strategi karir dilakukan sesuai dengan tujuan karirnya sehingga memberikan kemungkinan yang berbeda dari setiap individu baik ditinjau dari jenis pekerjaannya, tingkat jabatan maupun keahlian yang dimilikinya dalam menggunakan tipe strategi. Hal ini juga sesuai dengan hasil penelitian Nabi (2003); Rothwell dan Park (2009); Lau dan Pang (2000); Gould dan Penley dalam Creed dan Hughes (2012). Uraian tersebut menjelaskan bahwa career calling tidak dapat meningkatkan penggunaan strategi karir. Diketahui dari hasil analisis dalam penelitian ini bahwa career calling tidak memberikan sumbangan efektif sebesar 0.002 terhadap strategi karir, dengan demikian strategi karir tidak dapat menjadi perantara atau penguat hubungan career calling dengan perceived employability tetapi peningkatan career calling dapat meningkatkan perceived employability tanpa melalui strategi karir.

Berdasarkan hasil analisis jalur, diketahui bahwa strategi karir memberikan sumbangan efektif sebesar 0.263 terhadap 
perceived employability. Peran strategi karir terhadap perceived employability dapat dipahami berdasarkan model dari penelitian Praskova, Creed dan Hood (2015) tentang faktor yang menyebabkan terbentuknya perceived employability yang tinggi. Ditegaskan bahwa strategi karir berhubungan signifikan terhadap perceived employability. Individu yang cenderung menggunakan strategi karir dalam bekerja akan lebih banyak terlibat dengan aktivitas untuk meningkatkan perceived employability. Sesuai penjelasan dari Rothwell dan Arnold (2007); Cuyper, Van der Heijden dan De Witte (2011) individu yang mengembangkan perceived employability merupakan individu yang lebih produktif dan merasa bermakna dalam kehidupan di luar pekerjaannya.

Individu dengan career calling yang sesuai akan memperoleh makna yang penting tanpa menggunakan strategi karir sehingga ia akan lebih tertarik untuk terlibat dengan pekerjaannya melalui keahlian yang dimilikinya, merasa bahagia dan membuat pekerjaan menjadi lebih bermakna. Para pekerja profesi yang memahami career calling dengan baik akan melakukan tugasnya dengan memaksimalkan potensi dan keahlian yang dimilikinya dan hal tersebut berperan penting dalam peningkatan perceived employability. Kejelasan tugas dan tujuan yang harus diperoleh dari hasil kerja, bagaimana suatu pekerjaan harus dijalankan dan diselesaikan akan menimbulkan perasaan antusiasme dan semangat bekerja yang lebih baik. Sehingga para pekerja profesi akan menentukan sendiri tindakan yang tepat agar tugas dan tujuannya dapat tercapai melalui tindakan yang sesuai dan dibenarkan. Mereka juga dapat menentukan sendiri bagaimana harus bersungguh-sungguh untuk mempertanggungjawabkan hasil apa yang telah direncanakan dan dilakukannya sesuai dengan kebijakan organisasi dan kode etik profesi.

Berdasarkan penjelasan diatas, dapat disimpulkan bahwa strategi karir sebagai perantara career calling terhadap perceived employability dapat digantikan perannya dengan cara mengenali sumber career calling dan meningkatkan kapasitas perceived employability secara lebih baik lagi. Career calling yang bersumber sebagai religiusitas tidak memerlukan adanya penggunaan strategi karir karena pada dasarnya pekerjaan yang dilakukan dapat memberikan manfaat bagi orang lain, memberikan kepuasan dan makna hidup secara pribadi serta bernilai sebagai ibadah (Hirschi, 2011; Dik \& Duffy, 2009; Elangovan, Pinder \& McLean, 2010; Tasmara, 2002). Dilihat dari kategorisasi subjek, diketahui sebanyak 10.41\% (5 orang) memiliki strategi karir yang tinggi, $72.92 \%$ (35 orang) dalam kategori sedang dan $16.67 \%$ (8 orang) memiliki strategi karir dalam kategori rendah yang perlu menjadi perhatian bagi pihak organisasi.

Selain pengaruh tidak langsung antara career calling terhadap perceived employability yang dimediasi oleh strategi karir, dari hasil analisis jalur diketahui bahwa career calling secara langsung dapat mempengaruhi perceived employability. Diperoleh hasil pengaruh langsung career calling terhadap perceived employability dengan koefisien sebesar $1.279(\mathrm{p}<0.05)$. Selain itu, dari uji bootstrapping juga menunjukkan hal yang sama bahwa career calling memiliki pengaruh langsung terhadap perceived employability dengan koefisien sebesar 1.2781. Artinya career calling dengan aspek orientasi tindakan, rasa akan kejelasan tujuan dan misi pribadi serta tujuan pro-sosial juga dapat berpengaruh langsung terhadap perceived employability. Hal ini konsisten dengan penelitian yang dilakukan oleh Praskova, Creed dan Hood $(2014 ; 2015)$ bahwa career calling mempunyai pengaruh positif dan signifikan terhadap perceived employability.

Perceived employability pekerja profesi dapat meningkat ketika adanya career calling yang sesuai dengan dirinya, dimana kemampuan yang dimilikinya dapat digunakan dengan berbagai situasi dalam menyelesaikan tugas, memiliki kapasitas untuk melakukan kontrol pelaksanaan tugas hingga menyelesaikan suatu tugas serta memiliki hasil kerja yang baik. Sebagaimana dijelaskan oleh Fugate, Kinicki dan Ashfort (2004) bahwa perceived employability menentukan bagaimana individu dapat mengenali kemampuan yang dimilikinya, mencapai tujuan karir dan 
memungkinkan untuk memperoleh keuntungan lain. Para pekerja profesi yang merasakan perceived employability yang tinggi dengan pekerjaannya akan lebih banyak mengembangkan perilaku adaptif. Selain itu, mereka juga dapat melakukan kontrol diri secara lebih baik dan menunjukkan kinerja terbaik mereka pada organisasi (Fugate \& Kinicki, 2008).

De Cuyper, Van der Heijden dan De Witte (2011) menekankan pentingnya mengenali perceived employability. Hal ini akan menghantarkan individu menjadi lebih puas terhadap kehidupannya, menunjukkan kualitas kerja yang lebih baik dan akan lebih mencintai pekerjaannya. Melalui kemampuan fleksibilitas yang dilakukan dapat memberikan kemudahan beradaptasi terhadap semua jenis perubahan yang terjadi, memperoleh manfaat untuk perbaikan karirnya, lebih mudah melakukan perubahan dan memiliki pemahaman yang lebih baik terhadap pekerjaannya. Individu yang memiliki perceived employability dicirikan degan adanya identitas karir yang kuat, dapat menghadapi berbagai perubahan situasi dan mampu membangun jaringan sosial.

Berdasarkan kategorisasi skor subjek diketahui bahwa pekerja profesi di Kota Yogyakarta memiliki perceived employability yang sangat tinggi yakni $27.08 \%$ (13 orang) dan sebagian besar memiliki perceived employability yang tinggi yakni $72.92 \%$ (35 orang). Hal ini menunjukkan bahwa pekerja profesi di Kota Yogyakarta memiliki pemahaman yang baik terhadap kemampuan bekerja yang dimilikinya, mampu menjalankan pekerjaannya dengan baik dan mampu menghayati peran kerjanya secara lebih baik. Hasil penjumlahan pengaruh total career calling yang melibatkan strategi karir adalah sebesar 1.278, selain itu masih terdapat $52.8 \%$ variabel lain yang belum dapat dijelaskan oleh variabel career calling dan strategi karir terhadap perceived employability. Hal ini menjadi salah satu kekurangan penelitian ini yakni strategi karir tidak sepenuhnya memediasi kedua variabel dan ditemukan masih terdapat variabel lain yang mempengaruhi perceived employability selain career calling dan strategi karir seperti model psikologis, sumber daya kerja, kualitas kehidupan kerja, beban kerja, hubungan sosial dan kondisi pekerjaan.

Peneliti menyadari masih terdapat keterbatasan dan kekurangan lain pada penelitian ini. Oleh karena itu, peneliti berharap hal ini dapat dijadikan masukan atau bahan evaluasi bagi peneliti selanjutnya. Beberapa keterbatasan dalam penelitian ini yaitu masih terdapat beberapa pekerja dari masing-masing profesi yang tidak diikutsertakan dalam penelitian ini karena beberapa kendala lapangan. Terdapat kesenjangan antara fenomena strategi yang diperoleh dari data hasil penelitian dengan hasil pre-eliminary research. Berdasarkan hasil pre-eliminary research menjelaskan bahwa strategi karir pada pekerja cenderung tinggi sedangkan berdasarkan data hasil penelitian strategi karir tergolong rendah. Dengan demikian diharapkan penelitian ini dapat memberikan manfaat dan sumbangan baik secara praktis maupun teoritis dalam kajian strategi karir.

\section{Simpulan}

\section{Simpulan dan Saran}

Berdasarkan hasil analisis dan pembahasan yang telah dipaparkan, maka dapat disimpulkan:

1. Tidak terdapat hubungan yang signifikan antara career calling dan perceived employability dengan dimediasi strategi karir pada pekerja profesi di Kota Yogyakarta.

2. Terdapat pengaruh langsung yang signifikan antara career calling terhadap perceived employability. Hal ini menandakan bahwa tingginya kesadaran untuk mengenali sumber career calling akan meningkatkan pemahaman terhadap perceived employability tanpa menggunakan strategi karir pada pekerja profesi di Kota Yogyakarta.

\section{Saran}

Peneliti menyadari bahwa penelitian ini masih terdapat kekurangan diantaranya variasi pengambilan sampel yang masih kurang beragam, adanya perbedaan jenis rumah sakit yang berimbas pada pemahaman terhadap sumber career calling 
dan jumlah responden yang sedikit. Maka dari itu, untuk peneliti selanjutnya diharapkan lebih banyak mengkaji sumber referensi, melakukan perluasan dengan mempertimbangkan faktor lain yang mempengaruhi perceived employability maupun career calling seperti memfokuskan pengambilan sampel pada profesi dokter di rumah sakit swasta atau negeri. Selain itu, bagi penelitian selanjutnya dapat dilakukan pada profesi yang lain seperti perawat, wartawan atau profesi lain baik menggunakan metode kualitatif maupun eksperimen.

\section{DAFTAR PUSTAKA}

Azwar, S. (2011). Reliabilitas dan validitas. Yogyakarta: Pustaka Pelajar

Badan Nasional Sertifikat Profesi (BNSP). (2011). Pedoman BNSP 301 (Pedoman Pelaksanaan Asesmen Kompetensi Profesi) Revisi 1. Diunduh pada 25 Februari 2016, dari http://www.lspp.or.id/PEDOMAN301-Terbaru.pdf

Badan Pusat Statistik (BPS). (2002). Klasifikasi Buku Jenis Pekerjaan Indonesia (KBJI). Jakarta: Badan Pusat Statistik. Diunduh dari https://sirusa.bps.go.id/webadmin/d oc/KBJI2002.pdf

Berntson, E. (2008). Employability perception; nature, determinants and implication for health and well-being. Skripsi, Stockholm, Stockholm University: ISSBN 978-91-7155-636-3.

Creed, P. A. \& Hughes, T. (2012). Career development strategies as moderators between career compromise and career outcomes in emerging adults. Journal of Career Development, 40(2), 146-163. doi: $10.1177 / 0894845312437207$

Creed, P. A., Rogers, M. E., Praskova, A. \& Searle, J. (2014). Career calling as a personal resources moderator between environmental demands and burnout in Australian junior doctors.
Journal of Career Development, 41(6), 547-561. doi: $10.1177 / 0894845313520493$

De Cuyper, N., Van Der Heijden, B. I. J. M. \& De Witte, H. (2011). Associations between perceived employability, employee well-being, and its contribution to organizational success: A matter of psychological contracts?. The International Journal of Human Resources Managements, 22(7), 1486-1503. doi: $10.1080 / 09585192.2011 .561962$

De Cuyper, N., Vanhercke, D., Peeters, E. \& De Witte, H. (2014). Defining perceived employability: A psychological approach. Personnel Review, 43(4), 592-605. doi: 10.1108/PR-07-2012-0110

Dik, B. J. \& Duffy, R. D. (2009). Calling and vocation at work: Definitions and prospects for research and practice. The counseling Psychologist, 37, 424450. doi: 10.1177/0011000008316 430

Elangovan, A. R., Pinder, C. C., \& McLean, M. (2010). Calling and organizational behavior. Journal of Vocational Behavior, 76, 428-440. doi: 10.1016/j.jvb.2009.10.009

Fugate, M. \& Kinicki, A. J. (2008). A dispositional approach to employability: Development of measure and test of implications for employee reactions to organizational change. Journal of Occupational and Organizational Psychology, 81, 503527.

doi: 10.1348/096317907X241579

Fugate, M., Kinicki, A. J. \& Ashforth, B. E. (2004). Employability: A psycho-social construct, its dimension and applications. Journal of Vocational Behavior, 65, 14-38. doi: 10.1016/j.jvb.2003. 10.005

Ghozali, I. (2011). Aplikasi analisis multivariate dengan program IBM 
SPSS 19. Semarang: Badan Penerbit Universitas Diponegoro.

Greenhaus, J. H., Callanan, G. A. \& Godshalk, V. M. (2000). Career Management (3rd ed). New York: Dryden Press.

Hall, D. T. \& Chandler, D. E. (2005). Psychological success: When the career is a calling. Journal of Organizational Behavior, 26, 155-176. doi: 10.1002/job.301

Hirschi, A. (2011). Calling in career: A typological approach to essential and optional components. Journal of Vocational Behavior, 79(1), 60-73. doi: 10.1016/j.jvb.2010.11.002

Jobstreet.co.id. (2014). 73\% karyawan tidak puas dengan pekerjaan mereka. Diunduh pada tanggal 5 Februari 2016, dari

http://www.jobstreet.co.id/careerresources/73-karyawan-tidak-puasdengan-pekerjaanmereka/\#.Vrgvseu7rMI

Lau, A. \& Pang, M. (2000). Career strategies to strengthen graduate employees employment position in Hong Kong labour market. Education and Training, 42(3),135-149. doi: 10.1108/0040091001037268

Nabi, G. R. (2003). Situational characteristics and subjective career success: The mediating role of career-enhancing strategies. International Journal of Manpower, 24(6), 653-671. doi: $10.1108 / 01437720310496139$

Praskova, A., Creed, P. A. \& Hood, M. (2014).
The development and initial validation of a career calling scale for emerging adults. Journal of Career Assessment, 23(1), 91-106. doi: $10.1177 / 1069072714523089$

Praskova, A., Creed, P. A. \& Hood, M. (2015). Self-regulatory processes mediating between career calling and perceived employability and life satisfaction in emerging adults. Journal of Career Development, 42(2), 86-101. doi: $10.1177 / 0894845314541517$

Rothwell, A. \& Arnold, J. (2007). Selfperceived employability: Development and validation of a scale. Personnel Review, 36(1), 23-41. doi: $10.1108 / 00483480710716704$

Rothwell, A. \& Park, Y. (2009). The effects of organizational learning climate, career-enhancing strategy, and work orientation on the protean career. Human Resource Development International, 12(4).

Rothwell, A., Herbert, I. \& Rothwell, F. (2008). Self-perceived employability: Construction and initial validation of a scale for university student. Journal of Vocational Behavior, 73, 1-12. doi: 10.1016/j.jvb.2007.12.001

Tasmara, T. (2002). Membudayakan etos kerja islami. Jakarta: Gema Insani.

Van der Heijden, B. I. J. M. \& Van der Heijde, C. M. (2006). A competence-based and multi-dimensional operationalization and measurement of employability. Human Resource Management, 45, 449-76. doi: 10.1002/hrm.2011 